TEME, г. XLIII, бр. 4, октобар - децембар 2019, стр. 1125-1140

\author{
Оригинални научни рад $\quad$ https://doi.org/10.22190/TEME191026067O \\ Примљено: 26. 10. 2019. \\ UDK 663.99:343.3/.7(497.11)"2003/2019" \\ Ревидирана верзија: 1. 11. 2019. \\ Одобрено за штампу: 1. 12. 2019.
}

\title{
CLANDESTINE DRUG PRODUCTION LABORATORIES IN SERBIA
}

\author{
Božidar Otašević*, Dag Kolarević, Ivana Radovanović \\ University of Criminal Investigation and Police Studies, Belgrade, Serbia \\ božidarotasevic@yahoo.com
}

\begin{abstract}
The problem of the existence of illegal drug production laboratories in the world was recorded as early as in the mid-twentieth century. At the beginning of the twentieth century, this global problem affected Serbia, too, when the first clandestine drug production laboratories, whose production capacities exceeded the demands of the Serbian drug market, were uncovered. The aim of this paper is to determine the characteristics of illegal laboratories for the production of narcotics in the Republic of Serbia and how widespread they are. On the basis of the data provided by the Department of Analytics at the Ministry of the Interior of the Republic of Serbia, data relating to all illegal laboratories uncovered in Serbia (excluding Kosovo and Metohija) in the period from 2003 to 2019 was used. An exploratory research has been conducted analyzing 147 uncovered laboratories in which 245 illegal manufacturers were imprisoned. The production of marijuana took place in $92.5 \%$ of the laboratories, in $6.8 \%$ of cases synthetic drugs were produced, while hallucinogenic mushrooms were grown in one laboratory. A cartographic representation of how widespread the laboratories are and their basic characteristics in terms of location, production capacity and the type of installed equipment has also been provided.
\end{abstract}

Key words: drugs, illicit production, laboratory, marijuana, synthetic drugs.

\section{ТАЈНЕ ЛАБОРАТОРИЈЕ ЗА ПРОИЗВОДЫУ ДРОГА У СРБИЈИ}

\footnotetext{
Апстракт

Проблем постојања илегалних лабораторија за производњу дрога у свету забележен је још средином прошлог века. Овај проблем је са светског нивоа пресликан почетком овог века и на Србију, када су откривене прве тајне лабораторије за производњу дрога, чији су производни капацитети превазилазили потребе српског нарко-тржишта. Циљ рада је утврдити распрострањеност и карактеристике илегалних лабораторија за производњу опојних дрога у Републици Србији. На основу доступних података Управе за аналитику МУП-а Србије, обезбеђени су подаци који се односе на све илегалне лабораторије откривене у Србији (без Косова и Метохије) у периоду од 2003. до 2019. године. Спроведено је експлоративно истражи-
} 
вање у којем је анализирано 147 откривених лабораторија у којима је лишено слободе 245 илегалних произвођача. Производња марихуане одвијала се у 92,5\% лабораторија, у 6,8\% случајева реч је била о синтетичким дрогама, док је у једној лабораторији узгајана халуциногена печурка. Дат је и картографски приказ распрострањености лабораторија и њихове основне карактеристике у погледу локације, производних капацитета и типа инсталиране опреме.

Кључне речи: дрога, илегална производња, лабораторија, марихуана, синтетичке дроге.

\section{INTRODUCTION}

During the last decades of the twentieth century, drugs became increasingly widespread among young people. Throughout the world, drug production and drug trafficking was practically in the hands of organized crime and was one of its leading activities, a source of enormous wealth for individuals and an occasional cause of warfare between states. Because of the danger that drug addiction poses to every social community, states allocate substantial resources to suppress it, and research work also has its own significant place in this fight. The important aspect of this issue is the production of psychoactive controlled substances.

The scale of drug crime in the world is really massive. The scholars who research organized crime estimate that the annual turnover of global drug crime reaches a figure of almost 500 billion US dollars, and that at least $50 \%$ of all those involved in organized crime deal with drug crime (Kostić, 2000). When it comes to types of drugs, reports from international organizations as well as local research data (Jugović, 2004, p.180; Stanković, 2008; Radovanović and Lajić, 2016, p.345) indicate that cannabinoids are the most commonly used drugs both at the global and local level, while amphetamine-type stimulants (ATS) are the second most prevalent drug group. Unlike heroin and cocaine, whose production largely depends on the climate, they can be synthesized anywhere (Christian, 2004, p.32; Scott \& Dedel, 2006; UNODC, 2010; UNODC, 2016). Simple procedure, detailed instructions and recipes that can be easily accessed on the Internet, the necessary constituents which are easily accessible and in everyday use, have influenced the increase in the production and use of ATS.

The problem of the existence of illegal drug production laboratories in the world was recorded as early as in the mid-twentieth century. During the last two decades such illegal production has become more and more common both in the world and in our country. Over the years, the number of illegal laboratories has grown and has spread to other territories where such activities had not been registered before (UNODC, 2010; UNODC, 2012; Ahmad et al. 2014). The data provided by the European Monitoring Center for Drugs and Drug Addiction (EMCDDA), in a report relating to Serbia, show that synthetic drugs and precursors are smuggled to Serbia via the Balkan route. However, several large illegal laboratories for the production of 
synthetic drugs have recently been uncovered in Serbia. Based on the confiscated quantities of drugs, the equipment in the laboratories, as well as the amount of confiscated substances intended for production, experts estimate that the capacities of the laboratories exceeded the demands of the domestic market and that some of the drugs produced were intended for smuggling across Serbian borders (EMCDDA, 2009; Hadžić \& Zorić, 2009).

In terms of production capacity, the size of clandestine laboratories ranges from: a) those whose capacities are sufficient to meet the personal needs or demands of a small circle of users and to cover production costs, through b) those laboratories where only one part of the production process takes place, all the way to c) the laboratories that, according to their capacity, can be classified in the industrial production, the so-called 'super' or 'mega' laboratories. Although, according to some sources, about $80 \%$ of illegal laboratories fall into the category of small or the so-called 'kitchen' laboratories, large 'mega' laboratories provide almost $90 \%$ of the total quantity produced and their number is constantly increasing throughout the world (Scott, 2002; Scott \& Dedel, 2006; The Australian Government, 2011; Ahmad et al. 2014; Wright, 2015; ACIC, 2015/16). In terms of their location, laboratories can be found everywhere - in rural countryside areas, at the outskirts of cities, city shopping centers, but also in urban and residential areas, rented apartments and houses, sheds, garages, motel rooms, and even inside means of transport (Scott \& Dedel , 2006; Ahmad et al. 2014; Wright, 2015). However, residential premises are the most widespread location for clandestine laboratories.

The existence of illegal laboratories has multiple negative impacts on society. Although the unauthorized production of psychoactive controlled substances is a criminal offence per se, there are several other exceptionally negative consequences - physical injuries (due to explosions, fires, inhalation of toxic fumes and burns), endangering the health of people, especially children and endangering the environment, as well as association with other criminal activities (ONDCP, 2006; Scott \& Dedel, 2006; Ahmad et al. 2014). In addition to the standard consequences such as substance addiction, many other problems are related to the illicit production of substances - illegal trafficking and smuggling of these substances and precursors, human trafficking, corruption, fraud, robberies, etc. Moreover, according to certain reports, a large number of criminal offences with elements of violence are caused by pharmacological effects of methamphetamine (after a transient phase of euphoric mood, there is a phase in which users are prone to sudden mood swings, hallucinations, psychotic, paranoid and aggressive reactions, suicidal and homicidal tendencies occur (ONDCP, 2006; EnHealth, 2017) and victims of these violent acts (both physical and sexual) are often family members, especially children.

The subject of this paper is to investigate the basic characteristics of illegal drug production laboratories uncovered in the Republic of Serbia. 
The main aim of this paper is to determine the prevalence of illegal drug production laboratories, the trend of their uncovering, and to determine their basic characteristics (the level of their organization, quality of equipment used, type of drug produced, etc.). In addition to that, another aim of the paper is to evaluate the social threat and possible consequences of installing illegal laboratories (especially those intended for the production of synthetic drugs) and to provide recommendations for the work of police and judicial authorities in order to increase their efficiency in controlling the traffic of substances and equipment that may be misused in illegal production.

\section{METHODOLOGY}

The conducted research is exploratory in its character.

The basic hypothesis reads as follows: There are a significant number of illegal drug production laboratories on the territory of Serbia, and this situation is an important social issue.

In accordance with the determined aims of this research, specific hypotheses have also been made, as follows:

1. Synthetic drug production laboratories are characterized by a high level of organization, high quality equipment and considerable production capacity.

1a. During the time period covered by this research, a significant amount of confiscated drugs produced in these laboratories was recorded and, accordingly, a significant amount of illegally obtained financial gain.

2. Illegal drug production laboratories are significantly more frequently situated in large cities than in smaller towns or villages, due to better opportunities and easier procurement of equipment and raw materials.

3. According to the type of drugs, the most prevalent laboratories in Serbia are those for the production i.e. the cultivation of marijuana.

This research is exploratory in its character. It encompasses 147 illegal laboratories (laboratories that have been uncovered) for drug production on the territory of the Republic of Serbia (excluding Kosovo and Metohija) in the period from 2003 to 2019. The data that were used were provided by the Department of Analytics at the Ministry of the Interior of the Republic of Serbia, which records all cases of detection of clandestine laboratories on the territory of Serbia, regardless of whether they produce organic or synthetic drugs. Laboratories were analyzed depending on the type of drugs produced in them, the number of apprehended persons who participated in the production (one or more persons), the age of these persons, the number of police officers and the number of foreign nationals who participated in the unauthorized production of drugs. In addition to that, the number of clandestine laboratories uncovered per year was analyzed, according to the place of discovery of the clandestine laboratory (geographic location), 
according to the premises where the laboratory was located (ownership of the illegal manufacturer or rented space) according to the amount of confiscated drugs and money, and the amount of found weapons.

The analysis encompasses the production capacities of clandestine laboratories depending on whether professional or improvised equipment needed for the illicit production of drugs was used and whether all the production processes took place in one or more locations. Finally, the manner in which the laboratories were uncovered was analyzed (whether they were uncovered by routine police checks or operational work of the police, or whether these drug "factories" were uncovered by the criminal police at the Regional Police Directorates or by the Service for Combating Organized Crime, whether their discovery was preceded by any incident, at how many locations the laboratories were found (one or more laboratories within one criminal offence) and which type of equipment (improvised or professional equipment)).

IBM SPSS Advanced Statistics 20 package was used for the statistical data analysis.

\section{RESULTS}

Out of the total of 147 laboratories, 10 produced synthetic drugs (ecstasy - MDMA and amphetamines), one laboratory produced psilocin (a hallucinogenic mushroom), and the remaining 136 laboratories produced marijuana. A total of 245 perpetrators were registered, their average age being 39 (standard deviation is 9.5 years).

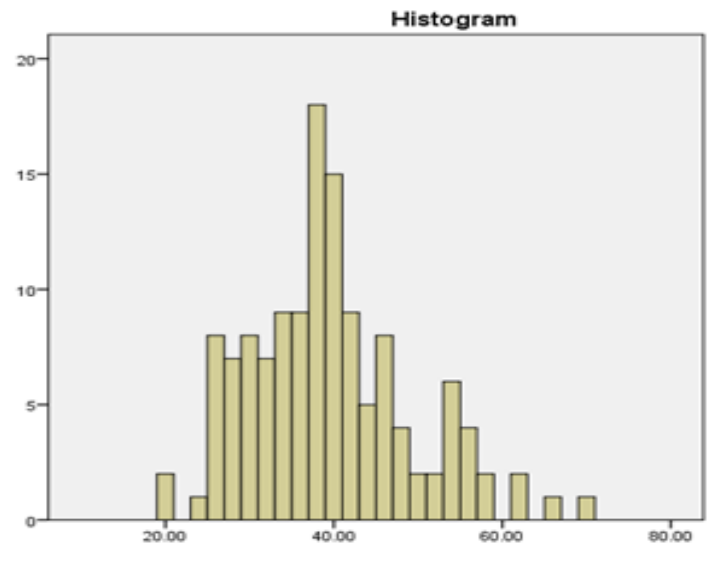

Graph 1. Age of perpetrators

Table 1 provides an overview of the type of drugs produced in the uncovered laboratories. Marijuana was produced in the majority of cases (92.5\%). The remaining drugs were synthetic drugs (6.8\%), whereas in 
one case a laboratory for the production of hallucinogenic mushrooms was uncovered - psilocin.

Table 1. Types of drugs in the uncovered laboratories

\begin{tabular}{lrr}
\hline Type of drugs & $\mathrm{F}$ & $\%$ \\
\hline Marijuana & 136 & 92.5 \\
Synthetic & 10 & 6.8 \\
Psilocin & 1 & .7 \\
\hline Total & 147 & 100.0 \\
\hline
\end{tabular}

Table 2 shows the results of the number of apprehended persons in clandestine laboratories. In almost two thirds of the cases, one perpetrator $(63.9 \%)$ was apprehended, in $17 \%$ of the cases two perpetrators were apprehended, in $4.1 \%$ of the cases three or four perpetrators were apprehended, while the remaining part of the cases included laboratories where five or more persons were apprehended. In three cases, laboratories were uncovered where no persons were found during the police incursion. Among the apprehended persons there were five police officers and two foreign nationals. A total of 245 people were apprehended in all laboratories, while 5 of them are still fugitives.

Table 2. Number of apprehended persons in laboratories

\begin{tabular}{lrcr}
\hline $\begin{array}{l}\text { Number of apprehended } \\
\text { persons per laboratory }\end{array}$ & F & $\begin{array}{c}\text { Total number of } \\
\text { apprehended persons }\end{array}$ & $\%$ \\
\hline 1.00 & 94 & 94 & 63.9 \\
2.00 & 25 & 50 & 17.0 \\
3.00 & 6 & 18 & 4.1 \\
4.00 & 6 & 24 & 4.1 \\
5.00 & 1 & 5 & .7 \\
6.00 & 1 & 6 & .7 \\
7.00 & 1 & 1 & .7 \\
10.00 & 3 & 30 & 2.0 \\
11.00 & 1 & 11 & .7 \\
\hline Total & 138 & 245 & 93.9 \\
Lack of data* & 9 & & 6.1 \\
Number of laboratories & 147 & & 100 \\
\hline \multicolumn{2}{c}{$*$ Uncovered laboratory without any apprehended perpetrators }
\end{tabular}

*Uncovered laboratory without any apprehended perpetrators

When it comes to the number of uncovered laboratories per year, in the period from 2003 to 2012 there was one uncovered laboratory each year (Graph 2). In the analyzed period, the smallest number of laboratories was uncovered in 2015, and after that the frequency increased; a small number of laboratories uncovered in 2019 results from the fact that the collected data refer to the first half of this year. The largest number of laboratories was uncovered in 2017 - a total of 34 of them. 


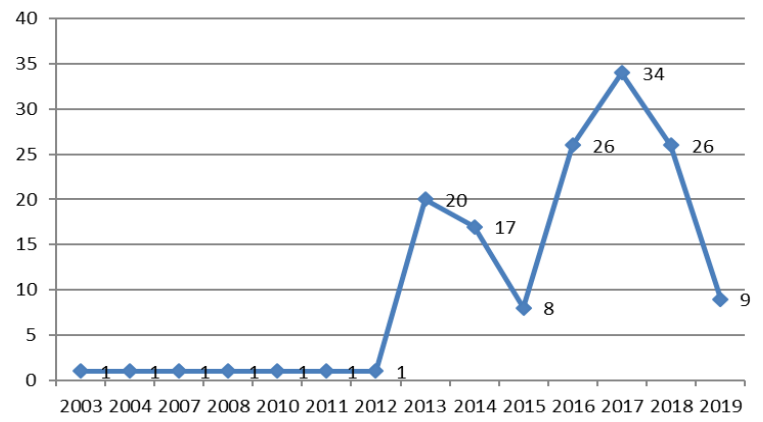

Graph 2. Number of uncovered laboratories per year

Figure 1 demonstrates the territorial layout of the uncovered laboratories in the territory of Serbia (excluding Kosovo and Metohija). Most were uncovered in Belgrade (42) and Novi Sad (13), followed by discoveries in Subotica (12), Niš (9), Kragujevac (6), Kruševac and Sombor with 5 laboratories each, and in Smederevo with 4. A smaller number of laboratories were uncovered in other cities.

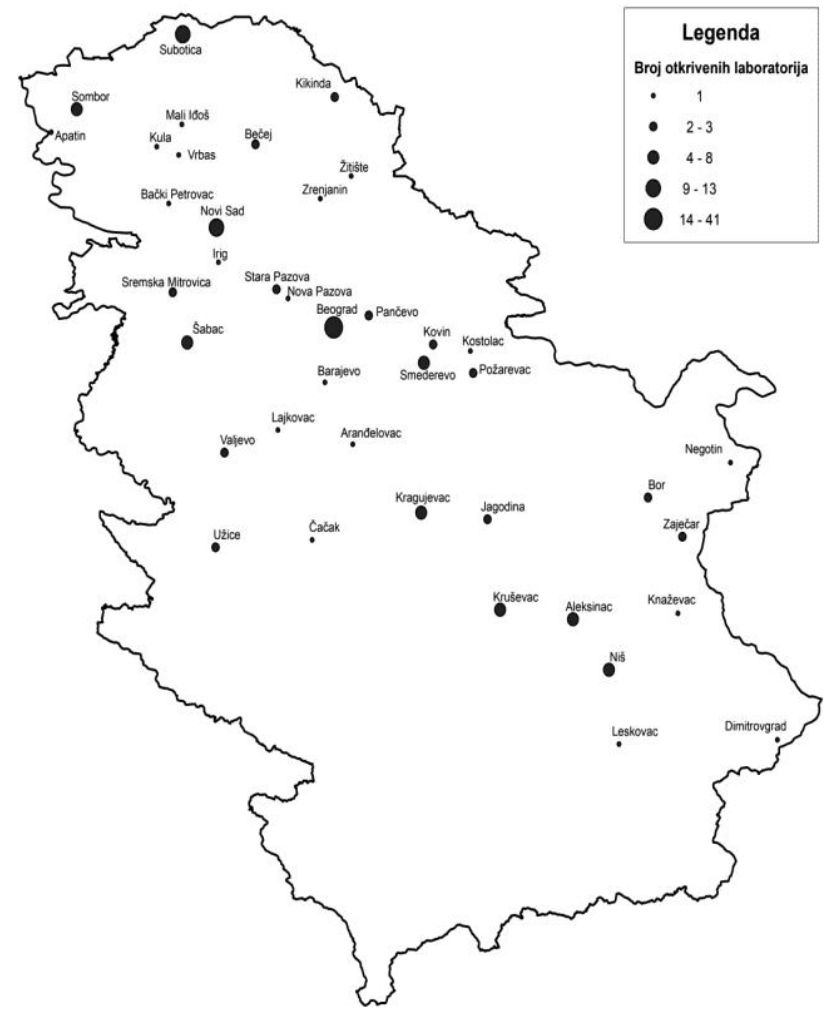

Figure 1. The number of laboratories uncovered according to crime scene 
Table 3 displays the total confiscation of drugs, money and weapons in the uncovered laboratories. During these police actions, the following were confiscated: 2,253.000 pills and 12.2 kilograms of various synthetic drugs, 12,908 kilograms of hallucinogenic mushroom - psilocin, 607.8 kilograms of dried marijuana ready for street sale, $772.66 \mathrm{~kg}$ of raw marijuana, 11,136 stems of marijuana and 6,540 pots of raw marijuana. The production process was underway at the time of their detection. During the incursion into the laboratory and the arrest of persons involved in the illicit production, a significant amount of weapons was uncovered, which reveals the criminal intent of the perpetrators of these criminal offences: 15 guns, 5 automatic rifles, 2 silencers, 2 optical sights, seven bombs and 300 pieces of ammunition of different caliber.

Table 3. Total confiscation in laboratories

\begin{tabular}{|c|c|c|c|}
\hline & Amount & Money & Weapons \\
\hline Number of pills & 2253000 & 10000000 euros & \\
\hline Synthetic drugs in $\mathrm{kg}$ & $12.2 \mathrm{~kg}$ & in one criminal & \\
\hline Psilocin (mushrooms) & $12908 \mathrm{~kg}$ & offence & 0 \\
\hline The amount of dried marijuana & $607.8 \mathrm{~kg}$ & 35060 euros and & ammunition, \\
\hline The amount of raw marijuana & $772.66 \mathrm{~kg}$ & 388000 dinars in & 7 bombs, 2 silencers, \\
\hline Number of marijuana stems & 11136 & other criminal & $1 \mathrm{sn}$ \\
\hline Number of marijuana pots & 6540 & offences & \\
\hline
\end{tabular}

The following table (Table 4) displays the descriptive results regarding the criminalistic characteristics of the uncovered laboratories. In the majority of cases, laboratories were uncovered as a result of the operational work of criminal police employees from regional police directorates $(93.2 \%)$, while the Service for Combating Organized Crime uncovered 10 laboratories $(6.8 \%)$ as a result of its operational work. The premises where illegal laboratories were situated were, in most cases, owned by illegal manufacturers, while a smaller part of the laboratories was installed in a rented space $-4.1 \%$ ( 6 of them). Highly professional equipment was found in 22 laboratories (15\%), which was in line with the production capacities of the laboratories uncovered, while in $85 \%$ of cases improvised laboratory equipment was found. The laboratories were mostly installed in one location $(90.5 \%$ ), while $9.5 \%$ or 14 laboratories were installed at two or more locations, which indicates that different stages of the drug production process took place at different locations. The laboratories were uncovered as a result of operational work of the criminal police. However, 3 laboratories were uncovered following an incident. In one of the cases, the chemicals intended for the illicit production of synthetic drugs were inadequately stored, which could have led to serious environmental pollution as highly toxic and carcinogenic waste leaked into the ground without control. In another case, the laboratory was uncovered after a fire had broken out. In the third case, an illegal manufacturer was wounded in a gun showdown in Belgrade. Having 
received medical assistance, he refused to give testimony to the criminal police officers, after which a search of apartments and other premises ensued only to discover an installed laboratory. Its production capacities indicated that the drugs produced had been intended for the illegal market for the purpose of obtaining financial profit, as revealed by the fact that the person in whose premises the drugs had been found was not a drug user.

Table 4. The criminalistic characteristics of the uncovered laboratories

\begin{tabular}{llrr}
\hline & & $\mathrm{F}$ & $\%$ \\
\hline $\begin{array}{l}\text { The organizational unit of the police } \\
\text { which uncovered the laboratory }\end{array}$ & Regional Police & 137 & 93.2 \\
& $\begin{array}{l}\text { Directorates } \\
\text { Service for Combating }\end{array}$ & 10 & 6.8 \\
& Organized Crime & & \\
\hline The real estate where the laboratory & in ownership & 141 & 95.9 \\
was located & in a rented space & 6 & 4.1 \\
\hline Was the equipment at the laboratory & improvised equipment & 125 & 85.0 \\
improvised or professional & professional equipment & 22 & 15.0 \\
\hline Was the laboratory installed at one or & one location & 133 & 90.5 \\
more than one locations & more than one locations & 14 & 9.5 \\
\hline Was the discovery of the laboratory & no incident & 144 & 98.0 \\
preceded by an incident & Incident & 3 & 2.0 \\
\hline
\end{tabular}

The relation between the type of drug and the laboratory equipment used stood out as a regularity in this research (Table 5). In all cases involving synthetic drug production, including the production of hallucinogenic mushrooms, highly professional equipment was used, whose production capacities exceeded the demands of the Serbian narcotics market, while most of the marijuana was grown under improvised laboratory conditions. Improvised and inexpensive laboratory equipment was installed in 125 laboratories dealing with illegal marijuana production, while in 11 laboratories highly professional equipment was found along with special Grow boxes filled with nutrient-rich soil and artificial lighting that allows the plant to grow without the presence of light (the so-called indoor cultivation).

Table 5. Type of drugs and type of laboratory equipment

\begin{tabular}{lccr}
\hline Type of drugs & \multicolumn{2}{c}{ Type of laboratory equipment } & Total \\
\cline { 2 - 3 } & Improvised & Professional & \\
\hline Marijuana & 125 & 11 & 136 \\
Synthetic & 0 & 10 & 10 \\
Psilocin & 0 & 1 & 1 \\
\hline Total & 125 & 22 & 147 \\
\hline
\end{tabular}

\section{DISCUSSION}

Out of the total number of laboratories detected in the analyzed period, $92.5 \%$ of cases were related to the illicit production of marijuana, 
which is the most widespread drug on the illegal market in almost all countries of the world, including Serbia. Marijuana is one of the oldest cultivated plants in world history. It can grow as a wild plant (weed) in all climates except in the polar zone and in tropical forests. It grows as a plant in our area as well, and can be grown outdoors and indoors. The subject of this analysis is the cultivation of marijuana under laboratory conditions (indoor), the so-called indoor cultivation. Based on the amount of confiscated drugs, the laboratory equipment, the amount of confiscated money and the period during which marijuana was grown under laboratory conditions, it can be concluded that the perpetrators intended to produce and sell it commercially. The number of laboratories uncovered (136) clearly indicates that illicit production is simple and easy to organize even at home. Information on how to cultivate marijuana is easily accessible and can be found on the Internet. Some presentations provide step-by-step procedures for its successful cultivation. There are also a number of tips on agricultural measures necessary to be taken for a good yield, including plant protection procedures and pesticides used in such production. For perpetrators of criminal offences with regard to the illicit manufacture of drugs, the Internet provides easy access to pharmaceutical, chemical and medical research data (Risimović, Bošković, 2018, p. 27). Drugs can be bought and sold online, hiding the identity of the parties involved in the transaction.

Illicit production of synthetic drugs was detected in $10(6.8 \%)$ laboratories, which is not a new problem for all those dealing with the issues of illicit production of synthetic drugs. The article entitled "The Fire Protection Service Should Know about Clandestine Drug Laboratories" came out in the US National Fire Protection Association Journal in November 1970. Today, one of the key problems in the USA is the illicit production of methamphetamine, which is simple and inexpensive. According to FBI data, in some cities in the western part of the USA, it has been reported that the number of apprehended persons involved in the production of methamphetamine exceeds the number of arrests of those who drive a motor vehicle under the influence of alcohol (Vernon, 2009).

After the USA, the first clandestine laboratories were uncovered in Europe, too - in the Benelux countries in the mid-1980s. Today, in addition to these countries, which are traditionally considered the largest manufacturers of synthetic drugs in Europe, a large number of illegal laboratories have also been uncovered in the countries of the former Eastern Bloc such as the Czech Republic, Poland and Hungary.

The first laboratory for the illicit production of synthetic drugs in Serbia was uncovered in 2003. It has turned out to be the largest illegal laboratory uncovered in the Balkans to date. The main organizer of this production was a Doctor of Pharmacy, M.Z, the owner of the "Lenel Farm" company. In an almost year-long police operation, about 10,000 MDMA ecstasy pills and about 20 tons of amphetamine sulfate (a mixture for the production of ecstasy with a total value of about 10 million euros) were 
confiscated, and the value of the uncovered "pharmaceutical" machines was slightly lower (Otašević, Atanasov, 2018, p.331).

Only 245 persons were imprisoned in 142 clandestine drug production laboratories, and in almost two thirds (63.9\%) of the cases only one perpetrator was apprehended. This information may point out to failures in police work, since during the operational work no link is established between illicit manufacturers and the rest of the criminal organization, although it is common knowledge that criminal offenses related to narcotics are generally group criminal offences with a hierarchical structure in its organization. A small number of apprehended persons may also indicate that the operational work of police services working to detect and prove these criminal offences is hampered by the careful logistics and organization of criminal groups, but also that this type of crime is the result of specialization where drug production cells are isolated from other elements in the drug trafficking chain such as transportation, resale or street drug sales.

The failures in police work are also revealed by the fact that in three cases no persons were found during the incursion into illegal laboratories. When the existence of an illegal laboratory is uncovered through operational work, then there is a possibility to monitor its work for a while, and therefore to plan the incursion into the laboratory (Otašević, 2017, p. 13). It is best to break into the laboratory and interrupt its work at a time when suspected and monitored persons are inside the laboratory and when the production process is underway. The incursion into an empty (without people) laboratory and not during production is in most cases counterproductive. In such cases, proving what exactly the laboratory produced can be very complicated.

The largest number of clandestine laboratories were uncovered in Belgrade (42), followed by Novi Sad, Subotica, Niš, Kragujevac, Kruševac and Sombor.

With regard to the illicit production of synthetic drugs, out of 10 uncovered illegal laboratories for the production of synthetic drugs, the largest number was detected in Belgrade and its surroundings - the total of 8 , and one laboratory each was uncovered in Novi Sad and Dimitrovgrad. Out of the total of ten laboratories detected, seven were involved in the illicit production of amphetamines, two in the illicit production of ecstasy and one in the production of the synthetic drug methaqualone. Out of 8 illegal laboratories uncovered in Belgrade, only two were uncovered in the inner city core, while 6 were uncovered on the outskirts. Two laboratories were installed in apartments, and 8 in specially equipped premises (Otašević, Atanasov, Dostić, 2018, p.80). Such laboratories can be installed in many different locations such as apartments, houses, basements, garages, utility rooms, sheds, attics, means of transport, trailers (Chiu, et.al., 2011, p. 356), and can be set up both in urban and rural areas.

The largest number of uncovered clandestine laboratories were in Belgrade, in accordance with the Public Security Strategic Assessment drafted by the Ministry of the Interior of the Republic of Serbia and officially 
published in 2017, which indicates that a total of 58 organized crime groups of different levels of organization have been registered in Serbia: 8.6\% - high level of organization, $44.9 \%$ - medium level of organization and $46.5 \%$ - low level of organization. Most organized criminal groups operate in Belgrade, and the predominant criminal activity of these groups is illegal production, smuggling and drug trafficking $(86.2 \%$ of registered organized criminal groups deal with the aforementioned $)^{1}$.

The amount of confiscated drugs in the marijuana production laboratories and synthetic drug laboratories is different, but if the quantities of drug and money confiscated are compared to the production capacity of the uncovered laboratories, it can be concluded that they were highly profitable laboratories, and that manufacturers did not leave "goods" to lie around for long, which means that the turnover rate was high. None of the detected illegal manufacturers produced drugs on a non-commercial basis, i.e., for their own or their friends' needs. The production of marijuana was intended for the demands of the local drug market, while the production capacities of the synthetic drug production laboratories exceeded the demands of the Serbian drug market so the manufactured drugs were smuggled to other countries as well.

Those laboratories were uncovered solely due to the operational work of employees of the criminal police. Only three laboratories were uncovered after incidents in laboratories, which is negligible data compared to other countries in Europe, especially the USA. For example, according to the DEA, about 6,500 methamphetamine laboratory incidents are annually reported in the USA, while at least three illegal manufacturers are killed in clandestine laboratories as a result of poisoning or explosions, while many others suffer injuries or burns (Vernon, 2009, p. 6). This data is confirmed by the results of a study conducted in the USA, where in $33 \%$ of cases the containers were pierced causing the chemicals to leak uncontrollably, while in $64 \%$ of cases there was a risk of combustion. Therefore, it is not surprising that fire broke out in 33\% of cases during the attempt to install a laboratory (Diplock, et.al. 2005, p.10).

Highly professional equipment was found in 22 laboratories (15\%), which was in line with the production capacities of the laboratories uncovered, while in $85 \%$ of cases improvised laboratory equipment was found. Contrary to the results of our research, the results of a research conducted in the USA based on analyzing files on uncovered laboratories suggest that in $16 \%$ of cases laboratory equipment was handcrafted; in $22 \%$ the used equipment was a mixture of handcrafted and professional items, while in the remaining $62 \%$ of the cases the equipment used was professionally produced (Diplock, et.al. 2005, p. 6).

\footnotetext{
${ }^{1}$ Source: Document of the Ministry of the Interior, Public Security Strategic Assessment, Belgrade, 2017
} 
In criminal law practice, there is a wide range of the type of equipment identified as incriminating in these premises. This is influenced by a number of factors: primarily whether organized criminal groups or individuals are in question; whether they engage professional or trained people; the type of drugs they produce; financial capabilities of criminal groups; the availability of equipment, chemicals, etc. Regardless of their size, the principle of production is the same for all of them (Otašević, 2018, p.14).

All of the laboratories dealing with the illicit production of synthetic drugs (10 of them) had professional production equipment and their production capacities exceeded the demands of the Serbian drug market. Everywhere in the world, and even in our conditions, these laboratories are the "ownership" of organized criminal groups that can only be confronted by a force of an organized state.

When it comes to the production of marijuana in laboratories, out of the 136 uncovered laboratories, high-quality production equipment was found only in 11 of them. The laboratories had professional Grow boxes filled with nutrient-rich soil and professional lighting. HPS grow lamps of 400 to $600 \mathrm{~W}$ were installed in them, which allow for constant and stable penetration power (light penetration), which directly affects the quality of the cultivated marijuana. In most of these laboratories, the so-called hormonal powder was also found, which affects the faster growth and formation of the woody part of the stem. Criminal law practice is also familiar with the application of innovative methods in the cultivation of marijuana, including the hydroponic method of cultivation when the plant is grown in a protected area without contact with the soil (Risimović, 2018, p. 260). The confiscated marijuana in the uncovered laboratories was of different quality and with higher percentage of THC as a carrier of psychoactive activity. This is significant because marijuana can be found to be significantly more potent in the illegal market, with higher THC percentage which can lead to health problems, i.e. delayed psychoactive effects three hours after consuming (vomiting, anxiety) caused by an overdose (Vandrey et al., 2017, p. 94-95). What also represents a health hazard is the fact that a large number of marijuana samples have confirmed contamination, i.e., the existence of fungi and bacteria that are harmful to health. The level of health risks is increasing when marijuana is produced in improvised laboratory conditions, which is the most common case in our country. In these laboratories, persons who do not have any formal chemical or pharmaceutical education are illegal manufacturers, and most of them learn about illicit production from criminal sources and networks. In these laboratories, manufacturers are drug dealers at the same time.

\section{CONCLUSION}

The number of uncovered laboratories and the amount of confiscated drugs in the last two decades suggest that the illicit production of drugs, 
especially synthetic drugs, is a serious social problem in our country. The largest number (42) of laboratories has been uncovered in Belgrade, where the highest numbers of organized criminal groups were registered - criminal groups whose predominant criminal activity is illegal drug production and trafficking. Moreover, illegal production is easier to set up in large cities because it is easier to obtain the raw materials and laboratory equipment necessary for larger production of both organic and synthetic drugs.

Only 245 people were imprisoned in 142 clandestine drug laboratories, and in almost two thirds (63.9\%) of the cases only one perpetrator was apprehended even though it is common knowledge that illicit drug production involves organization and strict delegation of tasks, where everyone knows exactly what they are responsible for in the illicit production chain. We believe that this situation is most often the result of the lack of preparedness of police to cope with the emerging circumstances, but also of poor legal regulations, especially in the area of control and traffic of substances and equipment necessary for illicit drug production. The failures in the methodology of uncovering and dismantling clandestine laboratories are also revealed by the fact that no persons were found in three laboratories during the police incursion. The basic rule of criminal work is that an incursion is carried out in the laboratory when the production process is underway and when the persons in charge of production are inside the laboratory. When the existence of an illegal laboratory is uncovered, then its work should be monitored for a while, and the incursion into the laboratory and arrest of the persons involved in different production stages should be planned in detail. The police must be able to investigate criminal organizations patiently and with regard to the time-period necessary to establish a clear image of their functioning and their manner of operation. This includes the systematic collection and analysis of data, the specialization of prosecutors and employees of the criminal police and the application of professional knowledge in an organized manner.

\section{REFERENCES}

Ahmad, F.L, Chang, K.H, Wan Nur Syuhaila, M.D, Maimonah, S., Raihanah, H. \& Kunalan, V. (2014). Clandestine Drug Laboratory: Emergence, Types, Factors and Problems. Health and the Environment Journal. 5(2):11-27.

Australian Criminal Intelligence Commission - Clandestine laboratories and precursors The Illicit Drug Data Report - IDDR 2015-16, accessed https://www.acic.gov.au/ files/clandestine-laboratories-and-precursors-iddr-2015-16-56219-kb, 25.09.2019.

Christian, D.R., (2004). Forensic investigation of clandestine laboratories. Boca Raton: CRC Press.

Diplock, J., Kirkland, S., Malm, A. \& Plecas, D., (2005). Clandestine drug laboratories in British Columbia, Centre for Criminal Justice Research (CCJR), University College of the Fraser Valley.

European Monitoring Centre for Drugs and Drug Addiction (2009). Serbia Country Overview 2009.

EnHealth (2017). EnHealth Guidance on: Clandestine Drug Laboratories and Public Health Risks accessed (2017) https://www1.health.gov.au/internet/main/ 
publishing.nsf/Content/A12B57E41EC9F326CA257BF0001F9E7D/\$File/Guidan ce-Clandestine-Drug-Laboratories-Public-Health.pdf , 25.09.2019.

Hadžić, P. \& Zorić, V., (2009). Ilegalne laboratorije za proizvodnju droge - policijska i kriminalistička obrada. [Illegal drug production laboratories - police and criminal processing]. Nauka, bezbednost, policija, 14(1),161-175.

Jugović, A., (2004). Rizična ponašanja omladine u Srbiji. [Risky behaviour of youth in Serbia]. U S. Mihailović (ur.), Mladi zagubljeni u tranziciji, str. (177-203). Beograd: Centar za proučavanje alternative.

Kostić, M. (2000). Proizvodnja i trgovina drogom unutar Evropske unije. [Drug production and drug trafficking within the European Union]. Bezbednost, 41(1), 121-132.

Office of National Drug Control Policy (2006), Methamphetamine and Related Crime: The Impacts of Methamphetamine Abuse, Northwest High IntensityDrug Trafficking Area Program, accessed http://www.npaihb.org/images/epicenter_docs/Meth/ docs/Methandrelatedcrime.pdf 25.09.20019.

Otašević, B., Atanasov, S., (2018). Sources of danger at the site of discovery of secret labs for drugs production. U S. Mijalković(ur). Thematic conference proceedings of international significance, Academy of criminalistic and police studies, „Archibald Reiss Days“ Belgrade, volume II, p. 330-337.

Otašević, B., (2018). Procedure na mestu otkrivanja tajnih laboratorija za proizvodnju droga. [Procedures at the Site of Discovery of Clandestine Drug Production Laboratories]. Bezbjednost, policija i građani, Banja Luka, 14(1): 3-20. doi 10.7251 BPG 18010030.

Otašević, B., Atanasov, S., Dostić, S., (2018). Sources of material evidence in the procedure fpr detection of clandestine labaratories for the manufacture of syntetic drugs: U M. Gurovski (ur.) 9th international scientific konference, Security system reforms as a precondition for euro - atlantic integrations, Skopje, vol. III, p. 78-88.

Radovanović, I., Lajić, O., (2016). Zloupotreba droge kao oblik kriminala maloletnika problemi istraživanja, fenomenološke karakteristike i odnos sa nekim poremećajima ponašanja. [Drug Abuse as a Form of Juvenile Crime - Research Problems, Phenomenological Characteristics, and Relationship with Certain Behavioural Disorders]. U: Kolarić, D. (ur.) Tematski zbornik radova Kriminalitet u Srbiji i instrumenti državne reakcije, p. 343-376.

Risimović, R., (2018). Da li je opravdana legalizacija medicinske i rekreativne upotrebe kanabisa? [Is the legalization of medical and recreational use of cannabis justified?] NBP-Žurnal za kriminalistiku i parvo, 23(3): 251-265. Doi 10.5937/ nabepo23-18781.

Risimović, R., Bošković, A., (2018). Neovlašćeno stavljanje u promet opojnih droga zloupotrebom interneta. Unlawful Circulation of Narcotics through Internet Abuse. Bezbednost, 60(3): 26-42. doi.105937/bezbednost1803026R.

Scott, M.S. (2002). Clandestine drug labs. U.S. Department of Justice, Office of Community Oriented Policing Service.

(2017). Strateška procena javne bezbednosti [Public Security Strategic Assessment], Ministarstvo unutrašnjih poslova Republike Srbije, Beograd.

Scott, M.S., Dedel, K., (2006). Clandestine methamphetamine labs. 2nd edition. U.S. Department of Justice, Office of Community Oriented Policing Service.

Stanković, M., (2008). Droga i kriminal. [Drugs and Crime]. Beograd:Simbol.

The Australian Government (2011). Clandestine Drug Laboratory Remediation Guidelines.

UNODC, (2010). World Drug Report 2010. United Nation of Drugs and Crime, Vienna: United Nations Publication.

UNODC, (2012). World Drug Report 2012. United Nations publication, Sales No. E.12.XI.1

UNODC, (2016). World Drug Report 2016. United Nations publication, Sales No. E.16.XI.7). 
Vernon, A., (2009). Clandestine Drug Labs Serious Dangers to Responders, decembar 15, dostupno na: www.firehouse.com/safety-health/article/10470318/clandestinedrug-labs-pose-serious-dangers-toresponders, accessed 15.01.2018.

Chiu, Y. N., Leclerc, B., \& Townsley, M. (2011). Crime script analysis of drug manufacturing in clandestine laboratories: Implications for prevention. The British Journal of Criminology, 51(2), 355-374. doi.org/10.1093/bic/azr005.

Vandrey, R., Herrmann, E. S., Mitchell, J. M., Bigelow, G. E., Flegel, R., LoDico, C., \& Cone, E. J. (2017). Pharmacokinetic profile of oral cannabis in humans: blood and oral fluid disposition and relation to pharmacodynamic outcomes. Journal of analytical toxicology, 41(2), 83-99. doi. org/10.1093/jat/bgx012.

Wright J. (2015). NSW Remediation Guidelines for Clandestine Drug Laboratories and Hydroponic Drug Plantation, A Report to Health Protection NSW.

\section{ТАЈНЕ ЛАБОРАТОРИЈЕ ЗА ПРОИЗВОДЫУ ДРОГА У СРБИЈИ}

Божидар Оташевић, Даг Коларевић, Ивана Радовановић

Криминалистичко-полицијски универзитет, Београд, Србија

\section{Резиме}

Број откривених лабораторија и количина заплењених дрога у последње две деценије упућују на закључак да је илегална производња посебно синтетичких дрога озбиљан друштвени проблем у нашој земљи. У 142 тајне лабораторије за производњу дрога лишено је слободе само 245 лица, а у скоро две трећине $(63,9 \%)$ случајева ухапшен је само по један извршилац - иако је опште познато да илегална производња дрога подразумева организацију и строгу поделу посла, где се тачно зна ко је за шта задужен у ланцу илегалне производње. Сматрамо да је овакво стање најчешће последица неспремности полиције да се снађе у новонасталим околностима, али и лоше правне регулативе, посебно у делу контроле и промета супстанци и опреме коja је неопходна за илегану производњу дрога. На пропусте у методици откривања и демонтирања тајних лабораторија указује и податак да у три лабораторије приликом упада полиције није затечено ниједно лице. Основно правило криминалистичког рада је да се упад у лабораторију врши када је процес производње у току и када се у лабораторији налазе лица која су задужена за производњу. Када се дође до сазнања о постојању тајне лабораторије, онда њен рад одређени период треба тајно надзирати и детаљно испланирати упад и хапшење лица која су укључена у различите фазе процеса производње. Полиција мора бити оспособљена да стрпљиво и у дужем временском периоду проучава криминалне организације, начин њиховог функционисања и њихове методе рада. То подразумева системско прикупљање и анализирање података, специјализацију тужилаца и припадника криминалистичке полиције и примену професионалних знања на организовани начин.

У највећем броју случајева, у тајним лабораторијама производила се марихуана (92,5\%). Остатак чине синтетичке дроге $(6,8 \%)$, док је у једном случају откривена лабораторија за производњу халуциногених печурака - псилоцин. У свим случајевима илегалне производње синтетичких дрога коришћена је скупа високопрофесионална опрема, чији су производни капацитети превазилазили потребе српског нарко-тржишта, па је дрога произведена у овим лабораторијама кријумчарена ван граница Србије. Када је у питању илегална производња марихуане у лабораторијским условима, такозвани унутрашњи узгој, од 136 лабораторија, само је у њих 11 нађена високопрофесионална опрема, док производни капацитети откривених лабораторија упућују на закључак да је дрога била намењена потребама локалног нарко-тржишта. 